\title{
Morphoanatomy, floral biology and reproductive phenology of Cambuí (Myrciaria floribunda (H. West ex willd.) O. Berg.)
}

\author{
José Dailson Silva de Oliveira ${ }^{1}$, Eurico Eduardo Pinto de Lemos ${ }^{2}$, Leila de Paula Rezende ${ }^{3}$, \\ Everton Ferreira dos Santos ${ }^{4}$, Ricardo Barros Silva ${ }^{5}$, Cibele Merched Gallo ${ }^{6}$
}

\begin{abstract}
Myrciaria floribunda is a species native to the restinga areas of the Atlantic Forest that presents great phenotypic variation in fruits, great socioeconomic importance in regions of natural occurrence and high productive potential. The characterization of heterogeneous populations is crucial for plant selection and breeding programs, since it allows the distinction of superior individuals. The aim of this study was to characterize the reproductive structure of M. floribunda accessions, and to observe the influence of climate and environment on its reproductive process, through floral biology, floral morphoanatomy and reproductive phenology. Apis mellifera and Trigona spinipes are the main floral visitors of cambuí. Stigma receptivity lasts up to 5 hours after flower opening and pollen viability was above $90 \%$. Regarding the flower structure, the female sexual organ is monocarpic, the ovary is efferent, bilocular, with two ovules per locule, the inflorescence is fascicle-like and consists of small white flowers, actinomorph symmetry, heteroclamid and monoclines. Plants bloomed irregularly throughout the year, concentrating flowering in two periods of the year with the greatest peaks in March and August, while the greatest fruiting peaks were observed in April and September.
\end{abstract}

Index Terms: inflorescence, fruiting, pollinators.

\section{Morfoanatomia, biologia floral e fenologia reprodutiva do Cambuí (Myrciaria floribunda (H. West ex Willd.) O. Berg.)}

Corresponding author: dailsonoliveira00@gmail.com

Received: June 19, 2021 Accepted: August 27, 2021

Copyright: All the contents of this journal, except where otherwise noted, is licensed under a Creative Commons Attribution License.

\section{(cc)) EY}

Resumo - A Myrciaria floribunda é uma espécie nativa das áreas de restinga da mata atlântica que apresenta grande variação fenotípica nos frutos, possui grande importância socioeconômica nas regiões de ocorrência natural e alto potencial produtivo. A caracterização de populações heterogêneas é determinante para um programa de seleção e de melhoramento de plantas, pois permite a distinção de indivíduos superiores. O objetivo deste estudo foi caracterizar a estrutura reprodutiva de acessos de $M$. floribunda e observar a influência das condições climáticas e do ambiente sobre o processo reprodutivo, por meio da biologia floral, da morfoanatomia floral e da fenologia reprodutiva. A Apis melifera e Trigona spinipes são os principais visitantes florais do cambuí. A receptividade do estigma tem duração de até 5 horas após a abertura da flor, e a viabilidade polínica esteve acima de $90 \%$. Em relação à estrutura da flor, possui órgão sexual feminino monocárpico, ovário ínfero, bilocular, com dois óvulos por lóculo, apresenta inflorescência do tipo fascículo, constituída por pequenas flores de coloração branca, simetria actinomorfa, heteroclamídeas e monoclinas. As plantas floresceram de forma irregular praticamente o ano inteiro, concentrando a floração em duas épocas do ano com maiores picos em março e agosto, enquanto os maiores picos de frutificação foram observados em abril e setembro.

Termos para Indexação: inflorescência, frutificação, polinizadores.

\footnotetext{
${ }^{1} \mathrm{MSc}$ in Agronomy (Plant Production). Department of Fruit Culture, Universidade Federal de Alagoas, Rio Largo-AL, Brazil. Email: dailsonoliveira00@gmail.com ${ }^{\text {(ORCID 0000-0001-8395-2856) }}$

${ }^{2} \mathrm{PhD}$ in Fruit Genetic Resources Conservation, Department of Fruit Culture, Universidade Federal de Alagoas, Rio Largo-AL, Brazil. Email: eurico@ceca.ufal.br (ORCID 0000-0002-0299-5676)

${ }^{3} \mathrm{PhD}$ in Agronomy (Plant Production), Department of Fruit Culture, Universidade Federal de Alagoas, Rio Largo-AL, Brazil. Email: leilarezende02@hotmail.com ${ }^{\text {(ORCID 0000-0002-9283-8745) }}$

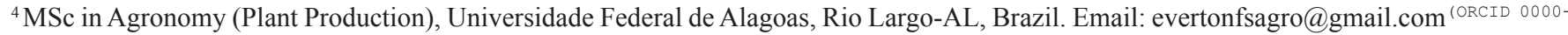
0001-5983-4681)

${ }^{5} \mathrm{PhD}$ in Agronomy (Plant Production), Universidade Federal de Alagoas, Rio Largo-AL, Brazil. Email: ricardoufal2010@gmail.com ${ }^{\text {(ORCID }}$ 0000-0002-0127-8325)

${ }^{6} \mathrm{PhD}$ in Agronomy (Plant Physiology), Faculdade São Vicente de Pão de Açúcar, Pão de Açúcar-AL, Brazil. Email: cibele.gallo@hotmail.com ${ }^{\text {(ORCID }}$ 0000-0002-0157-8504)
} 


\section{Introduction}

The inclusion of native species in production systems is a preservation strategy that generates economic returns and ensures plant biodiversity conservation (LAMARCA et al., 2020; GROPPO et al., 2019). But to ensure the insertion of species in production chains, it is essential to develop works aimed at generating information on the floral biology and the reproductive system of these species (GONÇALVEZ; VERÇOZA, 2017; TRAMONTIN et al., 2019).

Knowledge about the reproductive system of plants is especially essential for native species in the process of domestication and aimed at breeding, genetic conservation, seed production and adequate management, important to estimate the mode of transmission of genes from one generation to another (SOBIERAJSKI et al., 2007; GUSSON et al., 2006). This knowledge provides understanding about the interaction between plant and environment, identifying the best period for seed dispersal, phylogenetic relationships and greater availability of pollinators, allowing them to predict their reproduction periods, thus establishing sustainable use strategies and monitoring the impacts of exploration for the collection of fruits and for the species perpetuation (FERREIRA; CONSOLARO, 2013; FREITAS et al., 2013).

Myrciaria floribunda is a species native to the restinga areas of the Atlantic Forest that presents great phenotypic variation, great socioeconomic importance in regions of natural occurrence and high productive potential (DOS SANTOS, et al., 2017). The characterization of heterogeneous populations is crucial for a plant selection and breeding program, as it allows the distinction of superior individuals that can be directly released as cultivars or used as mother plants and gene source (KARIA et al., 2002).

The occurrence of ecological events associated with flowering and fruiting are possible due to the diversity of floral visitors and dispersing agents that are part of an organized morphophysiological and population system, and this relationship between flowers and pollinators is commonly pointed out as a result of interactions where flower structures facilitate the transport of pollen and interfere with the behavior of the insect vector to enable pollination (CASTRO et al., 2020; FAEGRI; PIJL, 2013).

In addition to understanding pollinators and dispersers, it is important to know the times of occurrence of these flowering and fruiting events through phenological studies, which are used to establish relationships between plant behavior and certain environmental conditions, in addition to being fundamental for crop planning and planting (FALCÃO et al., 2003; RÓS, et al., 2011).

The aim of this study was to characterize the reproductive structure of Myrciaria floribunda $(\mathrm{H}$. West ex Willd.) O. Berg. accessions, and to observe the influence of climatic and environmental conditions on its reproductive process.

\section{Methodology}

This work was carried out in the active germplasm bank of cambuí (BAG-cambuí) of the Campus of Engineering and Agricultural Sciences, Federal University of Alagoas (CECA/UFAL). To study the floral biology of Myrciaria floribunda, events such as anthesis, stigma receptivity, pollen grain viability and main floral visitors were observed. For the anthesis determination, the methodology described by Silva and Pinheiro (2007) was used, where flower structures were observed for 5 days, checking the opening times of flower buds and floral longevity. For this, 3 inflorescences of each accession were marked in 145 adult BAG-cambuí accessions.

For stigma receptivity, $3 \%$ hydrogen peroxide solution $\left(\mathrm{H}_{2} \mathrm{O}_{2}\right)$ was used (VOGEL, 1983); since $\mathrm{H}_{2} \mathrm{O}_{2}$ indicates the presence of the peroxidase enzyme through the formation of bubbles, indicating that the stigma was receptive. For pollen grain viability, anthers were sprayed on a slide and 100 pollen grains were randomly separated, which were stained with $2 \%$ acetic orcein, which stains the cell protoplasm in pollen grains, indicating viability (RADFORD, 1986). Slides were evaluated under optical microscope at 40x magnification (HISTER; TEDESCO, 2016).

The behavior of floral visitors was visually observed to determine the moment of occurrence of the highest visitation peak and some insects were captured with an entomological net to identify the species.

For the anatomical study of flowers, flower buds were collected from emergence to anthesis, dehydrated and embedded in paraffin to perform histological sections in rotary microtome, and slides with cross-sectional and longitudinal sections were stained with safranin and Erlich's hematoxylin, according to methodology described by Johansen (1940).

For the morphoanatomy analysis in scanning electronic microscopy (SEM), flower structure samples were separated and sections were manually performed, then metallized in gold evaporator (Quorum Technologies LTD, Ashford model Q 15 OR) for 10 minutes and finally taken to SEM (SILVA et al., 2018). Scanning electron photomicrographs were obtained using Shimadzu VEGA 3 LM-type coupled camera. In SEM, length and width measurements of flower structures were obtained.

For the phenology study, 145 9-year-old adult plants from BAG-cambuí CECA/UFAL were selected and weekly evaluated to verify the occurrence of flowering and fruiting events. Data obtained were compared to meteorological records using the method described by Fournier (1975), where the intensity of each phenophase is estimated using an interval scale with five categories, 
ranging from 0 to 4 with interval of $25 \%$ between each interval, where: 0 - absence of phenophase; $1=$ presence of phenophase with magnitude between $1 \%$ and $25 \% ; 2$ $=$ presence of phenophase with magnitude between $26 \%$ and $50 \% ; 3=$ presence of phenophase with magnitude between $51 \%$ and $75 \%$; and $4=$ presence of phenophase with magnitude between $76 \%$ and $100 \%$.

Where:

Fournier intensity percentage $=\frac{\sum \text { Fournier }}{4 \mathrm{~N}} \times 100$

$\mathrm{N}=$ Total number of plant populations.

\section{Results and discussion}

The flowering period of any plant species is marked by the presence of insects that are attracted by plants to facilitate or promote sexual reproduction. In cambuí ( $M$. floribunda), pollinating insects are not the only vectors responsible for the transfer of pollen from anthers to the stigma; however, they are responsible for the considerable increase in pollination efficiency. Anemophilia in Myrciaria floribunda results in low and uneven production.
Apis mellifera and Trigona spinipes (Figures $1 \mathrm{~A}$ and $1 \mathrm{~B}$ ) are the main floral visitors of cambuí, and the highest visitation peak is verified between 05:00 and 07:30 am. However, some insects of the same species remain until 11:00 am. The short visiting time of insects during the flowering season of $M$. floribunda is due to the availability of pollen of the species. This phenomenon is also common in other species of the same family, such as Campomanesia adamantium (CAMBESS.) O. Berg (NUCCI; ALVES-JÚNIOR, 2017). Pires and Souza (2011) evaluated the morphoanatomy and floral biology aspects of the species Myrcia laruotteana Cambesse (Myrtaceae) and Maués and Couturier (2002) studied the floral biology of Myrciaria dubia (HBK) McVaugh, and observed that these bees are also the main visiting insects, attracted by the sweet scent of flowers, in addition to being effective pollinators of Myrtaceae species.

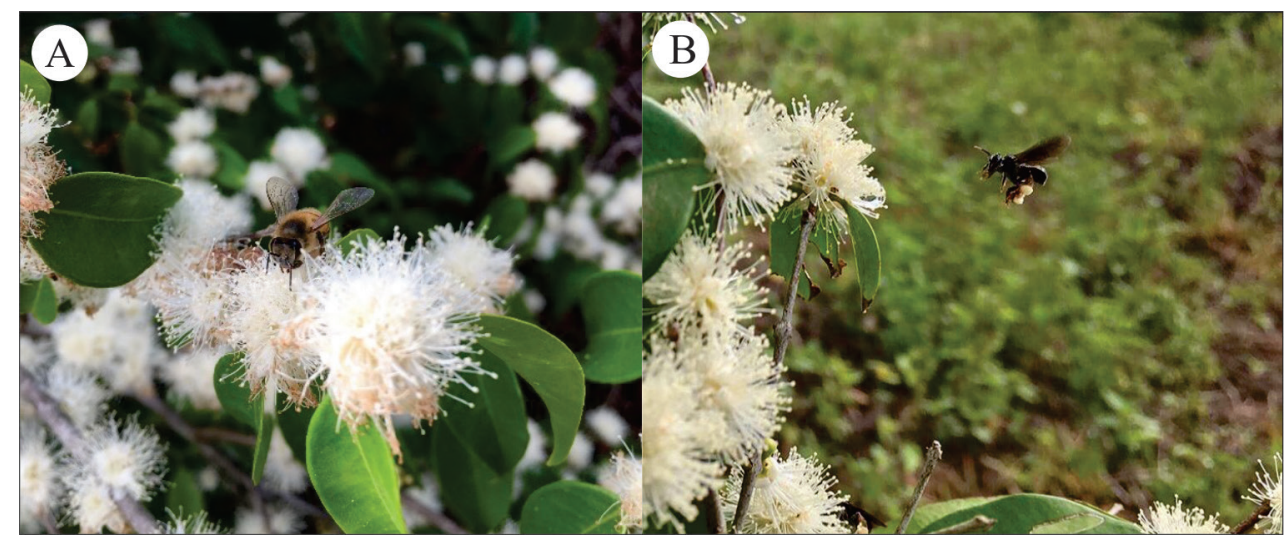

Figure 1. Apis mellifera and Trigona spinipes visiting Myrciaria floribunda (H. West ex Willd.) O. Berg. flowers.

Myrciaria floribunda has inflorescence (Figure 2A) of fascicle type (corymbia species) consisting of small hermaphrodite flowers (Figure 2B) of white color, with very short peduncles and with average of 15 flowers per bunch. Flowers are usually found in aphyllous nodes or in leaf axillae, have actinomorphic symmetry, heterochlamydum and monoclines, with four petals and four sepals that alternate with whitish coloration, anthers with four sporangia with long fillets. Caldas et al. (2020) reported that tree or shrub species belonging to the genus Myrciaria present inflorescences in leafy nodes, in glomeruli; persistent bracts and prophile. 


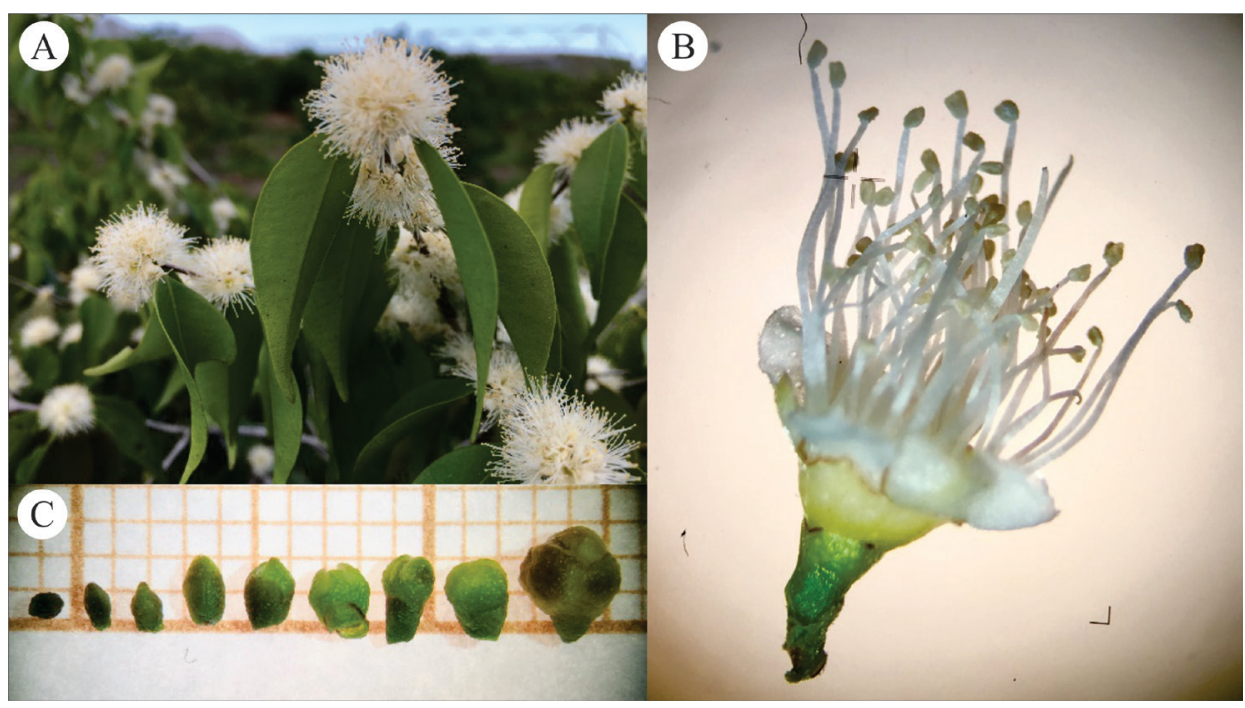

Figure 2. Myrciaria floribunda flower buds and flowers. A) Inflorescence with flowers in anthesis; B) open flower; and C) different flower bud development stages.

The development of flower buds (Figure 2C) from emergence to pre-anthesis takes an average period of 33 days and is marked by accelerated growth and mass gain, with pre-anthesis buds reaching more than three times the initial size of the flower bud, reaching average size of $3.0 \times 3.0 \mathrm{~mm}$, unlike other Myrtaceae that have larger flower buds, such as Eugenia rugosissima (6-7 x $4 \mathrm{~mm})$ and Myrcia isaianae (8-11 x 7-8 mm) (SOBRAL, 2006).

The successful pollination of the species may be intrinsically related to the reduced flower size, since visiting insects exhibit certain preferences for some floral attributes during the process of selection and recognition of plant species, and flower size directly implies the perception by the insect from touch, especially Apis mellifera bees that discriminate rewards found in flowers through tactile stimuli (SCHEINER, et al., 2005; MELO, et al., 2018).
Anthesis flowers, that is, flowers opened as a result of the maturing of sexual organs and beginning of the reproductive cycle, present a numerous amount of stamens and a very great visual highlight on the species. According to Barroso (2004), Myrtaceae flowers that occur in Brazil are hermaphrodites, normally white in color with numerous stamens and inferior ovary.

The average diameter of the M. floribunda flower (Table 1) found in this work was $3.642 \mathrm{~mm}$, being considered small when compared to most species belonging to the same family, in which diameter smaller than $15.0 \mathrm{~mm}$ is considered small and large when greater than $20.0 \mathrm{~mm}$ (GRESSLER, et al., 2006). The fillet size stands out, which is the largest structure of the cambuí flower, with average size of $4.37 \mathrm{~mm}$.

Table 1 - Average size of cambuí flower structures (Myrciaria floribunda). SE - standard error; CV - Coefficient of variation.

\begin{tabular}{l|cr}
\hline \multicolumn{1}{c}{ Structure } & Mean $(\mathbf{m m}) \pm$ SE & CV (\%) \\
\hline Flower diameter & $3.642 \pm 0.245$ & 6.73 \\
Stigma diameter & $0.264 \pm 0.017$ & 6.48 \\
Ovary diameter & $0.740 \pm 0.039$ & 5.25 \\
Pollen grain diameter & $0.011 \pm 0.001$ & 12.19 \\
Petal diameter & $2.080 \pm 0.230$ & 11.05 \\
Sepal diameter & $1.627 \pm 0.192$ & 11.78 \\
Fillet length & $4.377 \pm 0.173$ & 3.96 \\
Stylet length & $2.442 \pm 0.099$ & 4.07 \\
Number of stamens per flower & $57 \pm 2.173$ & 3.81 \\
\hline
\end{tabular}


The average diameter of the pollen grain observed in cambuí flowers was $11 \mu \mathrm{m}$, characterizing it as small when compared to other species of the same family, such as Syzygium jambos, which pollen grain has average diameter of $16.10 \mu \mathrm{m}$, but similar to the mean diameter observed in the pollen grain of Syzygium malaccense, which is $12.40 \mu \mathrm{m}$, values verified by Nacata et al. (2019), who studied pollen morphology and pollen and stigma availability in Syzygium. Hister and Tedesco (2016) found pollen grains ranging from $5 \mu \mathrm{m}$ to $10 \mu \mathrm{m}$ in araça (Psidium cattleianum Sabine). De França and Santos (2018) reported the importance of pollen grain size in pollination effectiveness, a characteristic directly related to dispersion, in which small pollen grains such as those of $M$. floribunda are easier to be transported by insects and are available in larger amounts for collection.
The pre-anthesis flower bud (figure 3A) observed using optical microscope shows the sexual structures of the Myrciaria floribunda flower, which has monocarpic female sexual organ, that is, with only one carpel, which is a structure composed of stylet, stigma and ovary. The ovary is classified as inferior, as it is located within the protective structure, which is the floral receptacle, below floral whorls formed by the calyx and corolla, being bilocular, which in other terms indicates that it has two chambers and two ovules per locule. Thus, it is possible to find fruits with up to four seeds, usually one more developed seed and three smaller seeds. However, it is more common to find fruits with one or two seeds. Pires and Souza (2011) evaluated the morphoanatomy and aspects of the floral biology of two Myrtaceae species and observed that the ovary of the two species is inferior, and that in Myrcia laruotteana Cambesse, it is bilocular, and in Myrcia guianensis (Aubletet) A.P. de Candolle, unlike M. floribunda, the ovary is trilocular.

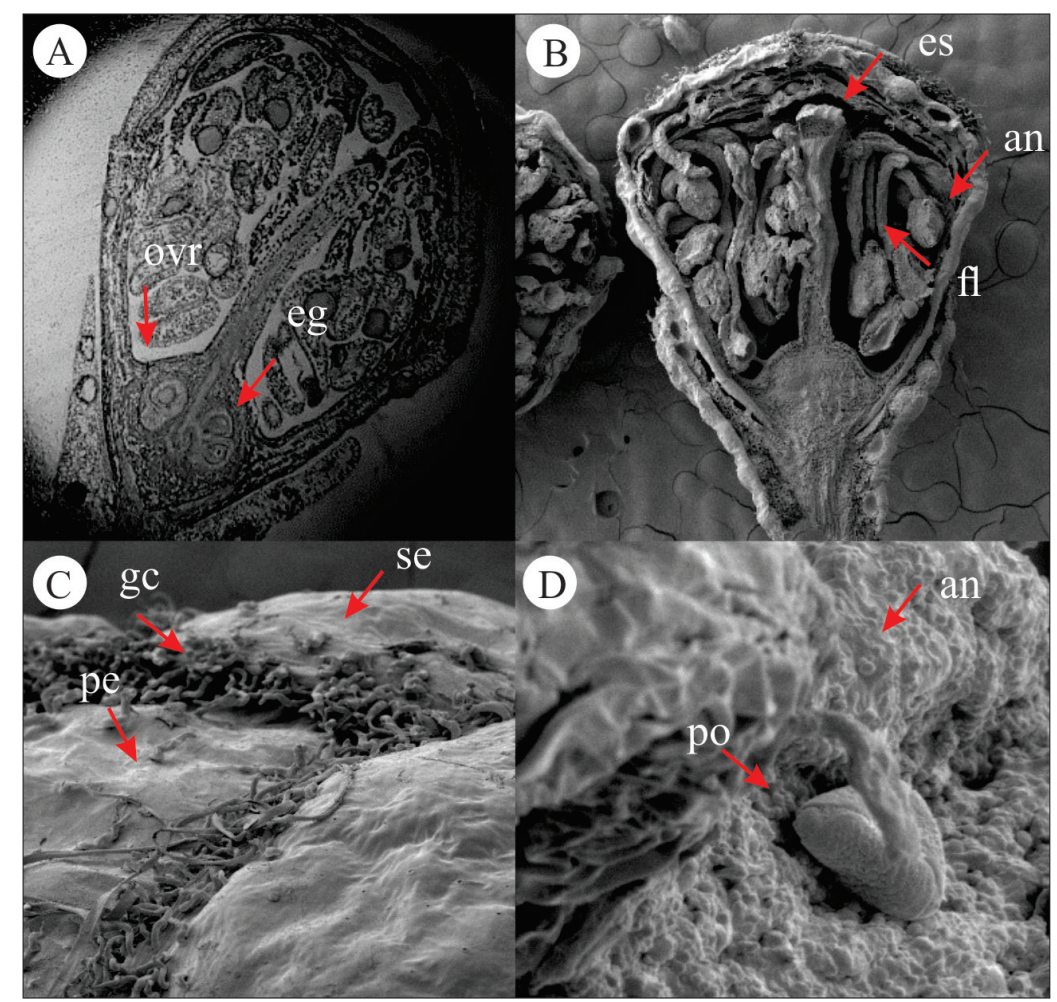

Figure 3. Myrciaria floribunda flower bud in A) optical microscope and B), C), D) in Scanning Microscopy. ovr ovary; eg - egg; es - stigma; an - anther; fl - fillet; pe - petal; se - sepal; gc - conspicuous glands; po - pollen. 
In figure 3B, the pre-anthesis flower bud is observed with the aid of scanning microscopy (SEM). It is possible to observe in detail the carpel and the anther, with glabrous stylet and the lower region of the pistil below an extended hypanthium. Anthers are characterized by having four sporangia and well-elongated fillets. Flowers have conspicuous glands (Fig. 3C) both in the calyx and in the corolla, occurring numerously on the edges of petals, which seem to have the function of secondary attractors for pollinators.

The pollen grain of M. floribunda, shown in 3D figure, assumes a triangular shape, a striking characteristic of the monophyletic group of Eudicotyledons that differentiate them from basal angiosperms, with these three openings or furrows, being, therefore, called triaperturate grains. Hister and Tedesco (2016) in a study on the estimation of pollen viability of araça (Psidium cattleianum Sabine) observed that the pollen grains of this species can have three different shapes: rounded, oval or triangular; however, only grains with triangular shape presented greater feasibility. Regarding the cambuí pollen grain viability, it was verified that more than $90 \%$ of grains are viable, results similar to those found by Pires and Souza (2011) in Myrcia guianensis (Aubletet) A. P. de Candolle.
Regarding stigma receptivity, it was observed that it lasts for a period of up to 5 hours after flower opening, determining the beginning of anthesis. However, pollination usually occurs in the first two hours of flower opening due to the presence of large numbers of pollinating bees. Maués and Couturier (2002) observed that the stigma of Myrciaria dubia (H.B.K.) McVaugh flowers also remained receptive for a period of up to 5 hours. In Myrcia guianensis (Aubletet) A.P. de Candolle and Myrcia laruotteana Cambesse, it was also observed that stigma receptivity lasts one morning (PIRES; SOUZA, 2011).

Myrciaria floribunda can show up to two flowering peaks during a one-year period (Figure 4). In this research, the reproductive cycle was evaluated between July 2019 and June 2020. Plants showed flowering peak between July and September 2019, reaching in August, 61.27\% of flowering individuals and Fournier intensity of $33.0 \%$. However, this peak was followed by a sharp drop in the following months, between October and December also in the year 2019, which together with January 2020 were the driest months of the evaluation period, with the lowest rainfall record, not exceeding $27.2 \mathrm{~mm}$ monthly, registered in December.

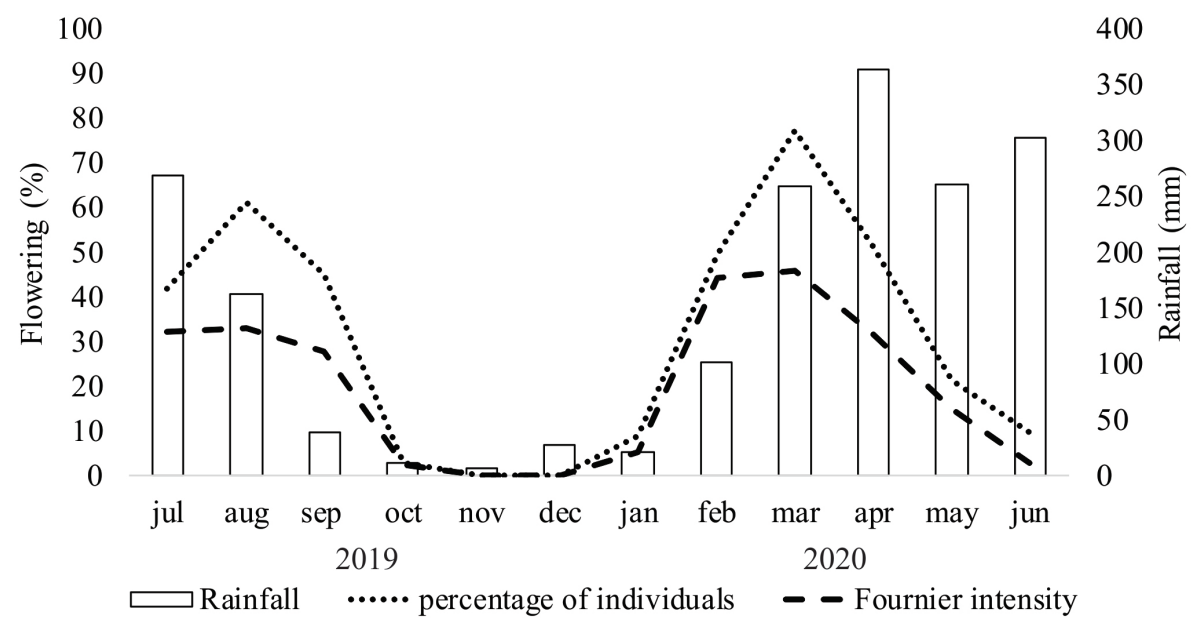

Figure 4. Phenological behavior of Myrciaria floribunda accessions native to the Northeastern region for the flowering phenophase ( $\mathrm{N}=145)$, according to two data analysis methods: percentage of individuals and Fournier intensity for cambuí flowering.

Due to climatic conditions, plants reached, in March 2020, the highest flowering peak recorded in a period of one year, with $77.24 \%$ of flowering individuals and Fournier intensity of $46.0 \%$. Castro et al. (2020), Nucci and Alves-Junior (2017) and Souza et al., (2007) observed that Eugenia sellowiana DC., Campomanesia adamantium (CAMBESS.) O. BERG and Calyptranthes concinna DC. showed only one flowering peak during a one-year period.
Lemos et al. (2018) reported that the flowering of cambuí in dry seasons promotes higher setting and production, while in rainy seasons, the higher floral abortion rate significantly impacts fruit production, unlike results obtained in this study, when seasons with higher rainfall index promoted greater production (Figure 6). However, fruit set effectiveness between the two seasons was not possible to observe, since the flowering and fruiting indices were not significant during the low rainfall period. 
Staggemeier et al. (2007) in a study carried out with 29 Myrtaceae species in the state of São Paulo, observed that flowering occurred during most of the year, except for the months of July and August, when none of the species had flower buds and flowers. It was also observed that the highest flowering peak occurred in January, reaching $37.9 \%$ of plants. The same authors also reported that there is a slightly seasonal pattern in the flowering season, but however, it occurred predominantly in the hot and rainy season.
Figure 6 shows the phenological data referring to cambuí fruiting, which lasts on average 41 days from anthesis to full fruit maturation (figure 5). This time is similar to that observed in Eugenia involucrata, which has maturation recorded in 43 days after anthesis (DAA), and much earlier when compared to araça, with fruit maturation occurring at 98 DAA (DANNER et al., 2010).

It is possible to observe (Figures 4 and 6) that the growing period of cambuí is restricted to the time of greatest water restriction, which may indicate physiological rest for energy accumulation or water stress suffered by the species, indicating that the crop responds to abiotic stimuli to start its reproductive cycle.

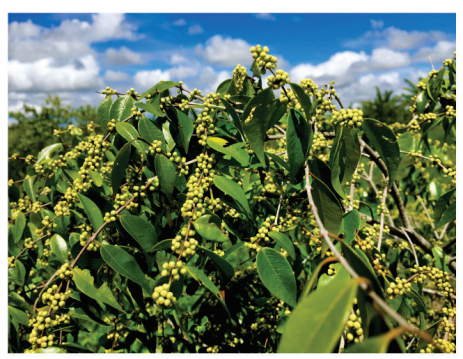

Flower buds

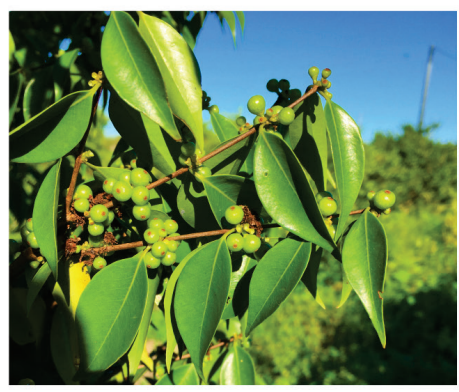

21 DAA

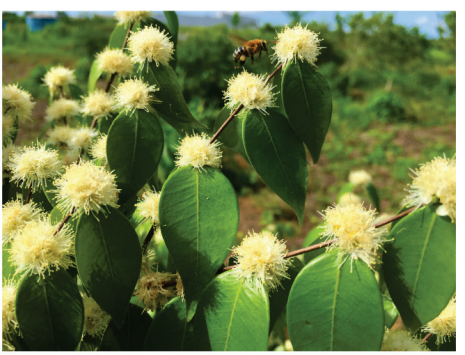

Flowers in anthesis

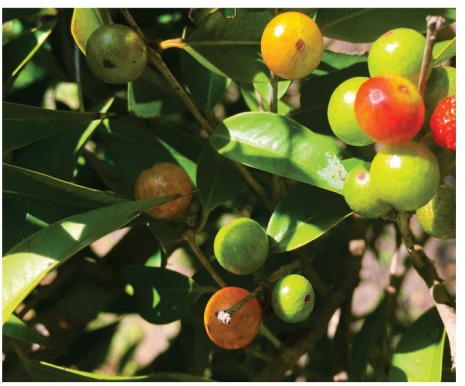

31 DAA

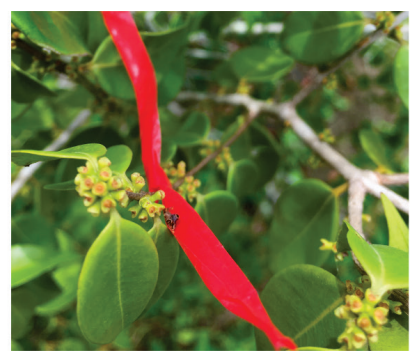

2 DAA

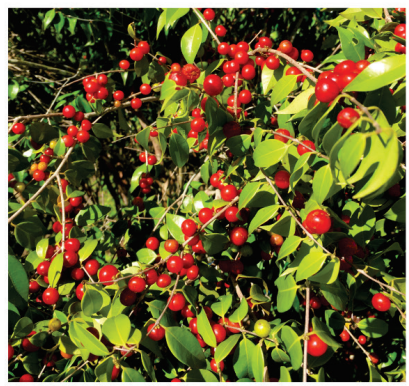

$41 \mathrm{DAA}$

Figure 5. Reproductive phenophases of Myrciaria floribunda accessions native to the Northeastern region. DAA Days after anthesis. 


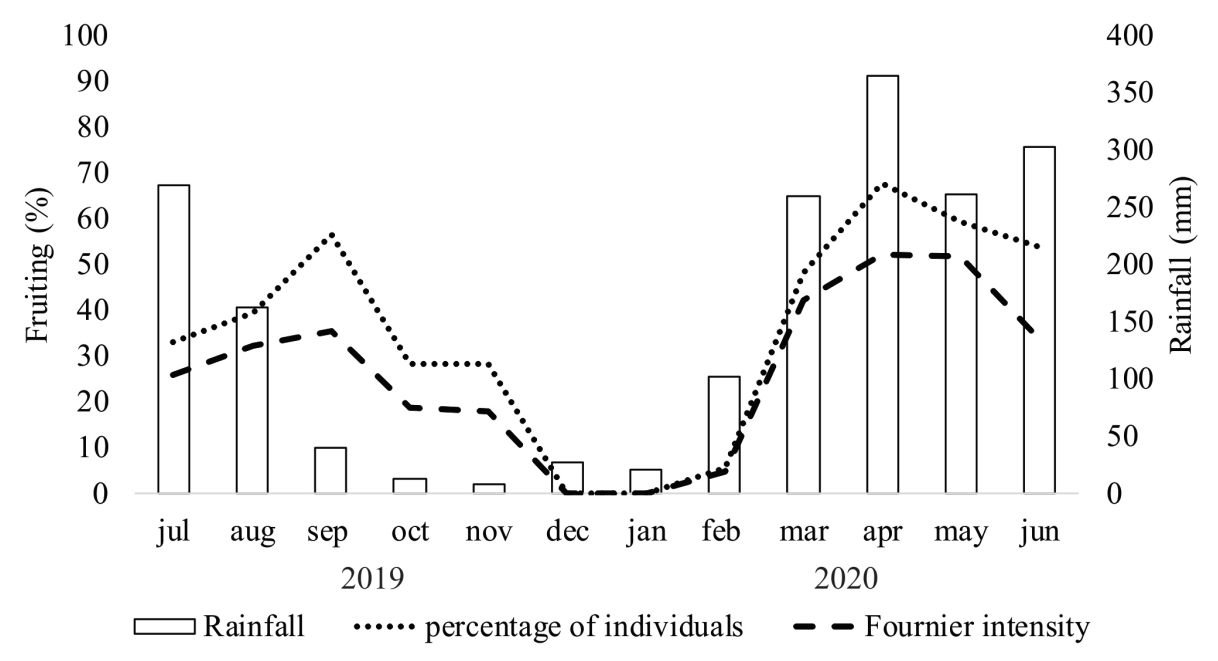

Figure 6. Phenological behavior of Myrciaria floribunda accessions native to the Northeastern region for the fruiting phenophase $(\mathrm{N}=145)$, according to two data analysis methods: percentage of individuals and Fournier intensity for cambuí flowering.

Cambuí accessions presented two fruiting peaks in a one-year period. The highest production peak was registered in April 2020, with more than 67\% of fruiting individuals and Fournier intensity of $52.07 \%$. This month also presented the highest rainfall peak $(364 \mathrm{~mm})$. Both flowering and fruiting peaks followed rainfall peaks.

Staggemeier et al. (2007) observed that the highest fruiting peak was also observed in April for the 29 Myrtaceae species under study, and the reproductive phenophase of Psidium cattleianum Sabine, Myrceugenia myrcioides (Cambess.) O. Berg and Gomidesia schaueriana O. Berg also persisted for most of the year.

\section{Conclusions}

Myrciaria floribunda flower structures observed in a morphoanatomical study showed remarkable aspects of the Myrtaceae family, being heterochlamyd, monoclines with monocarpic female sexual organ, glabrous stylet and numerous stamens, in addition to important aspects for the reproduction of the species, such as easy pollen grain transport due to its small size.

Climatic conditions are determinant for the reproductive cycle of the species, which has flowering and fruiting induced by rainfall and physiological rest during the period of lower rainfall.

The greatest ecological interaction of Myrciaria floribunda flowers occurred with Apis mellifera and Trigona spinipes bees, which are the main insects responsible for pollination.

\section{References}

BARROSO, G.M.; GUIMARÃES, E.F.; ICHASO, C.L.F.; COSTA, C.G.; PEIXOTO, A.L.; LIMA, H.C. Sistemática de angiospermas do Brasil. 2.ed. Viçosa: Editora UFV, 2004. $310 \mathrm{p}$.

CALDAS, D.K.D.; BAUMGRATZ, J.F.A.; SOUZA, M.C. Flora do estado do Rio de Janeiro: Myrciaria, Neomitranthes e Siphoneugena (Myrtaceae). Rodriguésia, Rio de Janeiro, v.71, p.01-31. 2020.

DALUZ FREITAS, J.; DOS SANTOS, A.C.; LIMA, R.B.; RABELO, F.G.; DOS SANTOS, E.S.; DE LIMA SILVA, T. Fenologia reprodutiva da espécie Carapa guianensis Aubl.(Andirobeira) em ecossistemas de terra firme e várzea, Amapá, Brasil. Biota Amazônia, Macapá. v.3, n.1, p.31-38, 2013.

DANNER, M.A.; CITADIN, I.; SASSO, S.A.Z.; SACHET, M.R.; AMBRÓSIO, R. Fenologia da floração e frutificação de mirtáceas nativas da floresta com araucária. Revista Brasileira de Fruticultura, Jaboticabal. v.32, n.1, p.291-295, 2010.

DE CASTRO, M.A.; PINHEIRO, L.F.; DE LUCENA, E.M.P. Fenologia vegetativa e reprodutiva da Eugenia sellowiana DC. (Myrtaceae) ocorrente no Jardim Botânico de São Gonçalo-Ceará. Revista Brasileira de Geografia Física, Recife, v.13, n.6, p.2760-2776, 2020. 
DE FRANÇA, R.; SANTOS, F.A.R. Análise volumétrica do pólen de Attalea funifera Mart. (Arecaceae) em amostras de pólen apícola do litoral do baixo sul da Bahia, Brasil. Paubrasilia, Porto Seguro, v.1, n.2, p.5-11, 2018.

FAEGRI, K.; VAN DER PIJL, L. Principles of pollination ecology. 3.ed. Oxford: Pergamon Press, 2013. 243 p.

FALCÃO, M.A.; CLEMENT, C.R.; GOMES, J.B.M. Fenologia e produtividade da sorva (Couma utilis (Mart.) Muell. Arg.) na Amazônia Central. Acta Botanica Brasilica, São Paulo, v.17, n.4, p.541-547, 2003.

FERREIRA, M.C.; CONSOLARO, H.N. Fenologia e síndromes de polinização e dispersão de espécies de sub-bosque em um remanescente florestal urbano no Brasil central. Bioscience Journal, Uberlandia, v.29, n.5, p.1708-1720. 2013.

GONÇALVES, V.F.; DE CASTRO VERÇOZA, F. Biologia floral e ecologia da polinização de Ipomoea alba L. (Convolvulaceae) em uma área de restinga no Rio de Janeiro. Revista Dissertar, Rio de Janeiro, v.1, n.26 e 27, p.76-79, 2017.

GRESSLER, E.; PIZO, M.A.; MORELLATO, L.; Patrícia C. Polinização e dispersão de sementes em Myrtaceae do Brasil. Brazilian Journal of Botany, São Paulo, v.29, n.4, p.509-530. 2006.

GROPPO, J.D.; SALEMI, L.F.; MORAES, J.M.; TREVISAN, R.; SEGHESI, G.B.; MARTINELLI, L.A. Capacidade de retenção de água do dossel vegetativo: comparação entre Mata Atlântica e plantação florestal de eucalipto. Ciência Florestal, Viçosa, MG, v.29, n.1, p.96-104, 2019.

GUSSON, E.; SEBBENN, A.M.; KAGEYAMA, P.Y. Sistema de reprodução em populações de Eschweilera ovata (Cambess.) Miers. Revista Árvore, Viçosa, MG, v.30, n.4, p.491-502, 2006.

HISTER, C.A.L.; TEDESCO, S.B. Estimativa da viabilidade polínica de araçazeiro (Psidium cattleianum Sabine) através de distintos métodos de coloração. Revista Brasileira de Plantas Medicinais, Botucatu, v.18, n.1, p.135-141, 2016.
KARIA, C.T.; DE ANDRADE, R.P.; CHARCHAR, M.D.Á.; GOMES, A.C. Caracterização morfológica de acessos do gênero Stylosanthes no banco ativo de germoplasma da Embrapa Cerrados-coleção 1994/1995. Planaltina: Embrapa Cerrados, 2002. 24 p. (Boletim de Pesquisa e Desenvolvimento)

LAMARCA, E.V.; OLIVEIRA JÚNIOR, C.J.F.; BARBEDO, C.J. Etnobotânica na conservação de espécies com sementes sensíveis à dessecação: o exemplo da Eugenia brasiliensis Lam. Hoehnea, São Paulo, v.47, p.1-9. 2020.

LEMOS, E.E.P.; REZENDE. L.P.; ARAÚJO, R.R.; ALVES, R.E. Myrciaria floribunda Cambuí. In: CORADIN, L.; CAMILLO, J.; PAREYN, F. G. C. (ed.). Espécies nativas da flora brasileira de valor econômico atual ou potencial: plantas para o futuro: região Nordeste. Brasília: MMA, 2018.

MAUÉS, M.M.; COUTURIER, G. Biologia floral e fenologia reprodutiva do camu-camu (Myrciaria dubia (HBK) McVaugh, Myrtaceae) no Estado Pará, Brasil. Brazilian Journal of Botany, São Paulo, v.25, n.4, p.441448, 2002.

MELO, L.R.F.; DA CUNHA B.M.G.; BARÔNIO, G.J.; DE OLIVEIRA, L.C.; CARDOSO, R.K.D.O.A.; ARAÚJO, T.N.; TELLES, F.J. Como as abelhas percebem as flores e por que isto é importante?. Oecologia Australis, Rio de Janeiro, v.22, n.4, 2018.

NACATA, G.; BELONSI, T.K.; GASPARINO, E.C.; ANDRADE, R.A.D. Morfologia polínica e viabilidade do pólen e estigma em syzygium (Myrtaceae). Revista Brasileira de Fruticultura, Jaboticabal. v.41, n.6, p.110. 2019.

NUCCI, M.; ALVES-JUNIOR,V.V. Biologia floral e sistema reprodutivo de Campomanesia adamantium (Cambess.) o. Berg-myrtaceae em área de cerrado no sul do Mato Grosso do Sul, Brasil. Interciencia, Caracas, v.42, n.2, p.127-131, 2017.

PIRES, M.M.Y.; DE SOUZA, L.A. Morfoanatomia e aspectos da biologia floral de Myrcia guianensis (Aubletet) AP de Candolle e de Myrcia laruotteana Cambesse (Myrtaceae). Acta Scientiarum. Biological Sciences, Maringá, v.33, n.3, p.325-331, 2011. 
RADFORD, A.E. Fundamentals of plant systematics.

New York: Harper \& Row, 1986.

RÓS, A.B.; HIRATA, A.C.S.; ARAÚJO, H.S.D.; NARITA, N. Crescimento, fenologia e produtividade de cultivares de mandioca. Pesquisa Agropecuária Tropical, Goiânia, v.41, n.4, p.552-558, 2011.

SCHEINER, R.; KURITZ-KAISER, A.; MENZEL, R.; ERBER, J. Sensory responsiveness and the effects of equal subjective rewards on tactile learning and memory of honeybees. Learning \& Memory, New York, v.12, n.6, p.626-635, 2005.

SILVA, A.E.D.S.; RODRIGUES, W.C.; CORDEIRO, W.D.L.; LIMA, P.R.; SOUSA, J.D.S.; FREITAS, A.J.D.D.; BARROS, D.D.A. Analysis of styrene polymerization without surfactant and N2 gas in cylindrical flask. Materials Research, São Carlos, v.20, p.800-807, 2018.

SILVA, A.G.; PINHEIRO, M.C.B. Biologia floral e da polinização de quatro espécies de Eugenia L. (Myrtaceae). Acta Botanica Brasilica, São Paulo, v.21, n.1, p.235-247, 2007.
SOBIERAJSKI, G.D.R.; BARBOSA, W.; BETTIOL NETO, J.E.; CHAGAS, E.A.; CAMPO-DALL'ORTO, F. A. Caracterização dos estágios fenológicos em sete cultivares e seleções de nogueira-macadâmia. Revista Brasileira de Fruticultura, Jaboticabal. v.29, n.3, p.690694, 2007.

SOBRAL, M. Três novas Myrtaceae de Santa Teresa, Espírito Santo, Brasil. Boletim do Museu de Biologia Mello Leitão, Santa Teresa, v.20, p.73-82, 2006.

SOUZA, M.D.C.; MORIM, M.P.; CONDE, M.D.M.S.; MENEZES, L.F.T.D. Subtribo Myrciinae O. Berg (Myrtaceae) na Restinga da Marambaia, RJ, Brasil. Acta Botanica Brasilica, São Paulo, v.21, n.1, p.49-63, 2007.

STAGGEMEIER, V.G.; MORELLATO, L.P.C.; GALETTI, M. Fenologia reprodutiva de Myrtaceae em uma ilha continental de Floresta Atlântica. Revista Brasileira de Biociências, Porto Alegre, v.5, n.S1, p.423425, 2007.

TRAMONTIN, M.; SANTOS, L.; PEDRI, E.C.; DARDENGO, J., ROSSI, A.A. Biologia floral de Theobroma speciosum Willd ex Spreng., uma Malvaceae nativa da Amazônia brasileira. Enciclopédia Biosfera, Jandaia, v.16, n.29, p.1911-1923. 2019.

VOGEL, S. Ecophysiology of zoophilic pollination. In: LANGE, O.L.; NOBEL, P.S.; OSMOND, C.B.; ZIEGLER, H. (ed.). Physiological plant ecology III. Heidelberg: Springer, 1983. p.559-624. 